\title{
Selektive utfordringer ved assistert befruktning for personer med Klinefelter syndrom
}

\author{
Bjorn Hofmann
}

Ny bioteknologi gir nye muligheter som har vist seg å vore moralsk utfordrende. Det gjelder sorlig innenfor menneskelig reproduksjon, der denne teknologien er spesielt potent. Med virkeliggjøringen av antikkens drøm om $\stackrel{a}{\circ}$ kunne påvirke fremtidige barns egenskaper følger en rekke vanskelige valg. I analysen av og debatten om slike valg har man forsøkt å skille mellom tilvalg og fravalg med hensyn på bestemte egenskaper. Ett konkret eksempel er hvorvidt personer med Klinefelter syndrom skal tilbys assistert befruktning, og det illustrerer at slike skiller kanskje ikke er så dekkende eller viktige for den etiske debatten som man kan få inntrykk av. Andre grunnleggende problemstillinger synes vel så påtrengende. Det betyr ikke at vi må forkaste seleksjonsmodellen. Eksemplet med Klinefelter syndrom stimulerer derimot til å revidere og utvi$k l e$ den, og det gir føringer for hvordan modellen kan nyanseres og anvendes ut over skillet mellom tilvalg og fravalg. Denne revisjonen kan redusere seleksjonsproblematikkens polemiske kraft, men kanskje også øke dens anvendelse for etikk i praksis.

Nøkkelord: seleksjon, sortering, reproduktiv teknologi, Klinefelter syndrom

\section{Innledning}

Argumenter mot «sorteringssamfunnet» har dominert den offentlige debatten om etiske utfordringer med ny bioteknologi generelt og reproduksjonsteknologi spesielt (Solberg 2003a; Saugstad 2007; Aftenposten 2008). Hensikten med bioteknologiloven er å «[...] sikre at medisinsk bruk av bio- 
teknologi utnyttes til beste for mennesker i et samfunn der det er plass til alle» (\$1-1). Sortering av mennesker oppfattes ofte som et brudd med denne målsettingen, noe som har gjort at spørsmålet om seleksjon har stått så sentralt.

Diskusjonen om sorteringssamfunnet ${ }^{1}$ har etablert et skille mellom

1 seleksjon fra (velge bort enheter på grunn av uønskede egenskaper, f.eks. skadelige tilstander);

2 seleksjon til (velge enheter på grunn av ønskede egenskaper).

«Enheter» refererer stort sett til befruktede egg eller fostre (Solberg 2003b; Bioteknologinemnda 2004; Solberg 2005; Bioteknologinemnda 2006a).

I denne artikkelen skal jeg undersøke en dagsaktuell problemstilling for å drøfte hvorvidt seleksjonsproblematikken er a) dekkende og b) vesentlig for en etisk debatt om bruk av moderne reproduksjonsteknologi. ${ }^{2}$ Problemstillingen er: Skal vi tilby assistert befruktning for menn med Klinefelter syndrom (KS)? Jeg vil bruke analysen av de moralske utfordringene som vi står overfor ved denne problemstillingen til å argumentere for at seleksjonsproblematikken verken er dekkende eller vesentlig for vurderingen av assistert befruktning for menn med Klinefelter syndrom. Samtidig kan analysen av de moralske utfordringene klargjøre og nyansere seleksjonsdebatten. Konklusjonen er at det er viktig å ikke la en forenklet seleksjonsproblematikk overskygge den etiske debatten om reproduksjonsteknologi.

\section{Hva er Klinefelter syndrom?}

Klinefelter syndrom (KS) ble beskrevet av Harry Klinefelter, Edward Reifenstein og Fuller Albright i 1942 som gynecomasti (forstørrede bryster hos menn), azoospermi, små testikler, forhøyede nivåer av follicle-stimulerende hormon (FSH) og hypogonadisme (Klinefelter 1942). I 1959 fant man at årsaken til KS skyldes et ekstra X-kromosom (XXY). Personer med KS har også blitt beskrevet som høye menn med smale skuldre og lange ben, lite kroppshår, lavt testosteronnivå (63-85\%), infertilitet (99\%), økt risiko for språk- og lærevansker ( $75 \%$ ) og dårligere psykososial tilpasning. Tradisjonelt har man også hevdet at det er økt risiko for lavere intelligens, noe nyere forskning bestrider.

Prevalensen er omkring 152/100 000 menn, det vil si 1 per 660 menn (Bojesen 2003). KS kan også forekomme som mosaikk, det vil si at noen celler er normale, mens andre har karyotypen 47,XXY. Det finnes ingen helt klar definisjon, og det antas å være en betydelig underdiagnostisering av KS (Bojesen 2007: 194f). 
Prognosen ved oppdaget 47,XXY er forholdsvis god, og ved tidlig oppdagelse av KS vil man kunne starte behandling og gi spesiell språktrening, noe som vil redusere symptomene betraktelig. På tross av dette velger $75 \%$ av danske kvinner abort (Bojesen 2003).

Personer med KS har en økt risiko for å utvikle diabetes, metabolsk syndrom, osteoporose, brystkreft, ulike kreftformer (mediastinal gern-cell tumors) og non-Hodgkins lymfom. I tillegg synes det å være en overhyppighet med hensyn på psykiatriske diagnoser.

Det anbefales utstrakt og livslang oppfølging av personer med KS. Livslang testosteronbehandling fra puberteten anbefales også, selv om det ikke finnes bevis på behandlingens effekt (Bojesen 2007). Videre anbefales intens språkobservasjon og språklæring ved behov.

Likevel oppfattes KS som en «mild tilstand» og ikke en «alvorlig funksjonshemming» (Råd for legeetikk 2007; Bioteknologinemnda 2007).

Ettersom menn med KS neste alltid er infertile, har de behov for assistert befruktning for å kunne bli fedre til genetisk egne barn, og det finnes mange metoder: PESA/TESA/MESA/TESE ${ }^{3}$ kombinert med IVF/ICSI (og ev. $\mathrm{PGD}^{4}$ ). På verdensbasis regner man med at det er født mer enn 60 barn av fedre med Klinefelter syndrom (Denschlag 2004; Schiff 2005), og i de fleste av disse tilfellene har barnet ikke KS. Det er kjent at assistert befruktning ved KS gir økt risiko for kromosomavvik, blant annet for KS, men det er fortsatt usikkert om det også øker risikoen for trisomi 13, 18 og 21.

\section{Seleksjon av sædceller, egg og gruppe}

Man kan hevde at ved PESA/TESA/MESA/TESE foregår det en «seleksjon til» når det gjelder hvilke sædceller som skal brukes. Egenskapene det velges ut fra, kan være mange, men det viktigste er viabilitet. Det vil være en tilsvarende «seleksjon til» for IVF (i kombinasjon med ICSI) ved valg av egg som skal tilbakeføres til kvinnen. ${ }^{5}$ Selv om disse tilvalgene gjøres for å få et friskt og sosialt velfungerende barn, er dette først og fremst tilvalg på et biologisk plan, og dermed et metodisk anliggende, mer enn seleksjon på bakgrunn av menneskelige egenskaper.

Valget av gruppe personer som skal tilbys assistert befruktning, for eksempel KS vs. andre grupper infertile menn, er et prioriteringsspørsmål mer enn et spørsmål om seleksjon til, men som vi skal se, vil seleksjonsspørsmålet gjøre seg gjeldende når man ikke kan utelukke sykdom eller bærertilstand hos barna. 


\section{Onsket om å få barn}

Den viktigste moralske grunnen til å tilby assistert befruktning til par der mannen har KS, er å hjelpe dem med å få genetisk egne barn. Ønsket om å få egne barn står sterkt i dagens samfunn, uavhengig av om behovet er sosialt eller biologisk betinget. PESA/TESA/MESA/TESE kombinert med IVF/ICSI (og ev. PGD) er en metode for å hjelpe infertile menn til å få genetisk egne barn.

Rettferdighetsbetraktninger taler også for at dette bør tilbys: I dagens samfunn har man $i$ andre sammenhenger gått langt $\mathrm{i}$ å hjelpe mennesker med å få barn, og det argumenteres for at man bør hjelpe mennesker selv om det medfører at barn får utviklingsavvik (Tännsjö 2008).

\section{Hvor stor reproduktiv frihet skal det enkelte individ (par) ha, og hvor viktig er genetisk farskap?}

Mens man tidligere bare kunne avhjelpe infertilitet hos kvinnen, gir ICSI og PESA/TESA/MESA/TESE menn hjelp med deres infertilitet. Disse metodene for assistert befruktning gir derfor en større symmetri mellom mann og kvinne innen assistert befruktning. ${ }^{6}$ Alternativene til PESA/TESA/ MESA/TESE + ICSI/IVF er sæddonasjon, adopsjon og barnløshet, der de to første kun gir sosialt farskap. PESA/TESA/MESA/TESE + ICSI/IVF utvider altså farens mulighet til også å bli genetisk far og øker med dette den reproduktive frihet. ${ }^{7}$

Når PESA/TESA/MESA/TESE + ICSI/IVF øker den reproduktive frihet hos mange infertile menn, kan begrensninger av en slik frihet oppfattes som paternalistisk. Samtidig vil nye muligheter også føre til et press for å benytte seg av dem, fordi det kan være stigmatiserende eller medføre forventet ubehag ikke å gjøre det («anticipated decision regret»).

Økt søkelys på genetisk farskap kan få følger for oppfatningen av sosialt farskap alene (adopsjon). For mange dreier dette seg om spørsmålet om hvorvidt det å bli genetisk far er et (legitimt) genetisk/biologisk behov eller en menneskerett. Poenget er at den nye reproduksjonsteknologien gir valgmuligheter, som oppfattes som et gode på flere måter, og at dette overskygger den underliggende seleksjonsproblematikken når man skal vurdere ny bioteknologi. $^{8}$

Verdien av å få et barn med arvemateriale fra mannlig partner synliggjøres dessuten av akseptnivået for risiko for utviklingsavvik hos barnet og abortrate. 


\section{Biologismens paradoks}

Når mange så sterkt ønsker å få genetisk egne barn, kan det skyldes et ønske om identitetsmessig nærhet til barnet: Man ønsker et «barn i sitt bilde» for at nærheten til barnet skal være så god som mulig. Det betyr at nærhet og identitet i stor utstrekning bygger på genetisk baserte egenskaper. Interessen for og etterspørselen etter assistert befruktning kan samtidig knyttes til et fertilitetsideal som bunner i en (evolusjons)biologisk forståelse av mennesket, der reproduksjon (det å føre genene sine videre) er blant de høyeste mål. For tilstander der infertilitet kan oppstå eller kan føres videre (som ved Klinefelters syndrom) synes dette å stå i skarp kontrast til evolusjonsbiologiens grunnlov om naturlig utvalg, der infertilitet er et klart fravalgskriterium. Å ha et evolusjonsbiologisk fundert reproduksjonsideal, men samtidig avstå fra evolusjonsbiologien når det gjelder seleksjon, kan virke motsigende, dersom man ikke har andre vektige argumenter som overskygger det «biologistiske paradoks».

Enten man har et (evolusjons)biologisk perspektiv eller baserer seg på sosiale rettigheter, kan det være utfordrende å begrunne en rett til reproduksjon generelt og til genetisk farskap spesielt.

\section{Alternativer}

Alternativet til PESA/TESA/MESA/TESE med påfølgende IVF (og ev. PGD) for par der mannen har KS, er altså sæddonasjon eller adopsjon. Ved sæddonasjon unngår man usikkerheten om hvorvidt det befruktede egget er genetisk disponert for KS, og kvinnen unngår IVF samt risiko for utviklingsavvik som følge av IVF. Samtidig kan det være langt mindre ressurskrevende. ${ }^{9}$ Det betyr at dersom det gjøres PESA/TESA/MESA/TESE, ICSI/ IVF og ev. PGD, har genetisk farskap en svært stor verdi (i et nytteetisk perspektiv).

\section{Hvor stor risiko kan vi akseptere, og hvem har ansvaret?}

Litteraturen antyder at det er økt forekomst av utviklingsavvik (kromosomavvik, gynecomasti, hypogonadisme, azoospermi, lærevansker og psykososial tilpasning) hos personer med KS. I tillegg øker risikoen for at barnet utvikler diabetes, metabolsk syndrom, osteoporose, brystkreft, ulike kreftformer (mediastinal gern-cell tumors) og non-Hodgkins lymfom. Samtidig synes tilstanden å beskytte mot enkelte sykdommer, for eksempel prostatakreft. Risikoen for at barnet får utviklingsavvik og utvikler sykdommer, er en betydelig moralsk utfordring. 
I tillegg kommer risikoen knyttet til bruk av PESA/TESA/MESA/TESE + ICSI/IVF + ev. PGD. Selv om det ikke er store forskjeller i risiko for utviklingsavvik mellom PESA/TESA/MESA/TESE + ICSI/IVF og IVF, så er det en forhøyet risiko i forhold til fødsler uten bruk av avansert reproduksjonsetknologi. Forskjellen antas i hovedsak å skyldes den økt risikoen ved flerlingefødsel. Nyere studier antyder imidlertid at risikoen er knyttet til infertiliteten eller dens determinanter (Zhu 2006). Dersom mannlig infertilitet eller dets determinanter selv er en risiko for utviklingsavvik hos barnet, er dette prinsipielt utfordrende. Uansett er en forhøyet risiko en moralsk utfordring, fordi det kan bryte med grunnleggende helsefaglige prinsipper om ikke å påføre skade. ${ }^{10}$

Dessuten er det vesentlig å se at PESA/TESA/MESA/TESE + ICSI/IVF er en metode der risiko og nytte ikke bæres av en og samme person. Det reiser spørsmålet om hvor langt kan man gå i å behandle en person (kvinnen) for uønskede tilstander hos en annen person (mannens infertilitet). I hvilken grad er personene som utsettes for risiko, fri (for sosialt press)? Er kvinnen fri for press fra mannen ved valg av PESA/TESA/MESA/TESE + ICSI/ IVF som metode for assistert befruktning, sammenlignet med for eksempel sæddonasjon? ${ }^{11}$

Dette understreker hvor viktig det er med informasjon om belastninger, bivirkninger, risiko for abort og for utviklingsavvik hos barnet, blant annet når det gjelder samtykke.

Det er vanskelig å sette noen absolutt risikogrense, men høy risikotoleranse kan være uttrykk for parets eller mannens sterke ønske om genetisk farskap. Risikoproblematikken reiser dermed spørsmål om ansvar: I hvilken grad er helsevesenet ansvarlig for resultatene når man forestår assistert befruktning? Hvem skal i tilfelle stille helsevesenet til ansvar? Foreldrene kan ikke gjøre det: De har samtykket og ønsket behandlingen. En person som er født ved hjelp av ICSI og som har store utviklingsavvik, kan ikke holde infertilitetsklinikkene eller helsevesenet ansvarlige for sine utviklingsavvik, selv om det barnet som hadde blitt født ved hjelp av andre alternativer, kunne ha blitt friskt. Grunnen til det er at man kan hevde at det ville ha vært et annet menneske. Valget står derfor ikke mellom barn med eller uten utviklingsavvik, men mellom to barn - et uten og et med (mulig) utviklingsavvik.

Dette reiser altså, som ved mange andre typer reproduksjonsteknologi, spørsmålet om forholdet mellom reproduktiv frihet, risiko (Harris \& Holm 1998; Harris 2004; Elsner 2006) og ansvar. Når det gjelder valg av antall befruktede egg som skal tilbakeføres, har parene i praksis liten selvbestemmelse: Så godt som alle par får tilbakeført ett befruktet egg, og resten fryses ned for senere bruk (cryopreservering) (von Düring 2007). Begrunnelsen er risikoen for utviklingsavvik for barnet knyttet til flerlingefødsel. Her er den reelle reproduktive friheten svært begrenset. Ved bruk av PESA/TESA/ 
MESA/TESE+ICSI/IVF for par der mannen har KS, legges det (som i andre forhold der det er risiko knyttet til assistert befruktning) avgjørende vekt på parets selvbestemmelse. I det første tilfellet tar fagpersonellet ansvaret, i det siste overføres ansvaret i stor grad på paret selv. I det første legges det vekt på hensynet til barnet når det gjelder risiko for utviklingsavvik, i det siste er dette mindre vektlagt.

Det er ikke vanskelig å tenke seg tilfeller der enkelte par ønsker flerlingefødsel, fordi det er hensiktsmessig å få to barn samtidig, og de er villige til a ta risikoen knyttet til flerlingefødsler. Det kan virke motsigende at man ikke skal ha reproduktiv frihet til dette, mens man ellers har stor reproduktiv frihet til å akseptere risiko på vegne av et fremtidig barn.

Risikoproblematikken er sentral for vurderingen av å tilby assistert befruktning til personer med KS, men heller ikke den fanges opp av diskusjonen om seleksjon til eller fra.

\section{Er det riktig å viderefore en tilstand som man selv oppfatter som uonsket?}

Som antydet er det også en viss risiko for at årsaken til den uønskede tilstanden (infertilitet) føres videre til barnet, for eksempel ved mikrodelesjoner på Y-kromosomet eller ved KS. Dette er relevant i forhold til en uttrykt bekymring for redusert sædkvalitet for menn i Skandinavia (Jørgensen 2006) og i forhold til å overføre noe som man selv oppfatter som negativt til en annen person (barnet).

Det kan hevdes at dette siste representerer en fare for å redusere vedkommende til bare et middel for sin egen genetiske reproduksjon, og at man dermed underordner barnets velferd. Mot dette kan det argumenteres at også barn unnfanget på vanlig vis kan være tilsiktet primært som et middel (f.eks. med tanke på en trygg alderdom). Dessuten blir de fleste foreldre glade i sine barn uansett opprinnelige intensjoner, og man kan hevde at «alle barn er glade for å være født». Videre vil samme behandling være tilgjengelig for barnet, og det vil være det enkelte par som velger for sitt barn, og som vil stå ansvarlige for valget. ${ }^{12}$

Utfordringen med argumenter som angår videreføring av sykdommer generelt og frykten for å øke den mannlige infertiliteten som følge av medisinske inngrep (Kremer et al. 1998) som ICSI spesielt, er at det bygger på fordommer om disse sykdommene eller på negativ eugenikk, i betydningen å redusere muligheten til reproduksjon for personer med genetiske defekter eller som antas å ha uønskede arvelige egenskaper.

Selv om dette er en seleksjon fra, er det ikke vanskelig å tenke seg situasjoner der risikoen for barnets helse øker betraktelig som følge av farens arveegenskaper, og der dette vil oppfattes som et dilemma for både inferti- 
litetsklinikkene og helsevesenet. I land med høy forekomst av enkelte arvelige utviklingsavvik, som Iran og Kypros, der behandling av disse tilstandene beslaglegger store deler av helsebudsjettet, har man innført tiltak som førekteskapelig screening for å begrense antall barn med tilstandene (Bozkurt 2007; Abolghasemi et al. 2007). Det betyr at de viktige distinksjonene ikke gjøres mellom seleksjon fra eller ikke, men ut fra hvor alvorlig tilstanden oppleves i en sosial kontekst.

\section{Barnets beste}

Hensynet til barnets beste gjør seg gjeldende særlig på to områder: risiko for utviklingsavvik hos barnet og vurdering av psykososial egnethet til å bli foreldre. Som vi har sett ovenfor, er risikovurderingen relevant for vurdering av antall egg som settes inn, men ikke i like stor grad for utviklingsavvik eller valg av metode for assistert befruktning (les sæddonasjon vs. PESA/ TESA/MESA/TESE + ICSI/IVF), der det henvises til parets selvbestemmelse (og ansvar). Dessuten kan den reproduktive atferden til foreldre med normal fertilitet føre til stor risiko for utviklingsavvik hos deres barn. For eksempel er det $50 \%$ sannsynlighet for at et par der en av personene har dominant systenyrelidelse, får barn med samme tilstand. Dette brukes som argument for at det ikke kan legges vekt på risiko for barnet i forbindelse med assistert befruktning. Andre vil legge vekt på forskjellen mellom tjenester som tilbys av helsetjenesten og aktiviteten som foregår i den private sfære.

I Norge kreves det medisinsk og psykososial vurdering av par som $ø$ nker assistert befruktning. Selv om flere av symptomene ved KS kan diskvalifisere for farskap, er det vanskelig å ekskludere personer med KS generelt. Det skyldes store variasjoner. ${ }^{13}$ Dessuten kan kategorien KS være ytterligere stigmatiserende dersom man vedtar at tilstanden diskvalifiserer til assistert reproduksjon. Det taler for at slike vurderinger bør foregå individuelt.

Britiske Human Fertilisation and Embryology Authority (HFEA) har fire kategorier for vurdering av par som søker assistert befruktning (HEFA 2005):

1. Prinsippet om barnet sitt beste bør fjernes frå lovgivinga fordi foreldra sin autonomi alltid bør komme før muligheten en tredjepart har til å hindre at et barn blir født.

2. Det at et medisinsk miljø er involvert ved assistert befruktning betyr at en tredjepart har et visst ansvar i forhold til barnet som blir født. Hensynet til pasienten (her foreldrene) sin autonomi tilsier likevel at 
klinikken bare skal nekte å behandle dersom det er overhengende fare for at barnet kan komme til alvorlig psykisk eller fysisk skade.

3. Det at et medisinsk miljø er involvert ved assistert befruktning plasserer et betydelig ansvar for barnet hos en tredjepart. Klinikken skal ikke tilby behandling med mindre de føler seg trygge på at barnet si velferd ikke blir påverka negativt.

4. Prinsippet om barnet sitt beste i lovgivinga bør styrkast slik at barnet sitt beste er det som betyr mest når en avgjør om en skal hjelpe et par (eller et individ) til å bli foreldre. ${ }^{14}$

Mens Sosial- og helsedirektoratet har foreslått retningslinjer i tråd med HEFAs kategori 2, så har Bioteknologinemnda foreslått en kategori mellom 2 og 3 der det heter at klinikken ikke skal tilby behandling dersom det er fare for at barnet kan komme til psykisk eller fysisk skade (Bioteknologinemnda 2006b). Hensynet til barnet i forhold til foreldrenes psykososiale egnethet er en nødvendig betingelse for assistert befruktning, men ikke en tilstrekkelig betingelse: Ikke alle foreldre som er psykososialt skikket, vil få tilbud om assistert befruktning.

Tabell 1 Sosial vurdering av par med hensyn på assistert befruktning i henhold til HEFA og Bioteknologinemnda

\begin{tabular}{|l|l|l|l|}
\hline $\begin{array}{l}\text { Moralsk Kunnskap: } \\
\text { utgangspunkt: }\end{array}$ & $\begin{array}{l}\text { Sikre på fare } \\
\text { for skade }\end{array}$ & $\begin{array}{l}\text { Sikre på at det } \\
\text { ikke fare for } \\
\text { skade }\end{array}$ & $\begin{array}{l}\text { Usikkerhet om fare } \\
\text { for skade }\end{array}$ \\
\hline $\begin{array}{l}\text { Tillatt: Bare nekte } \\
\text { hvis }\end{array}$ & HEFA 2 & $\begin{array}{l}\text { Bioteknologi- } \\
\text { nemnda }\end{array}$ \\
\hline $\begin{array}{l}\text { Forbudt: Bare tillate } \\
\text { hvis }\end{array}$ & & HEFA 3 & \\
\hline
\end{tabular}

\section{Er mannlig infertilitet en alvorlig sykdom som skal prioriteres?}

Prioritering er både et moralsk og et helseøkonomisk anliggende. Ufrivillig barnløshet er en tilstand som oppfattes som svært alvorlig av dem det gjelder. Enten det er på grunn av et genetisk behov for å få barn, eller det skyldes sosialt press, ønsker personene seg svært mye å få hjelp til å få barn. Dersom man sammenligner PESA/TESA/MESA/TESE + ICSI/IVF med andre behandlingsformer i det norske helsevesenet, ser det ut til at effektiviteten og kostnadseffektiviteten er lav, særlig hvis man tar hensyn til belastningen for kvinnen og økt antall barn født med utviklingsavvik. PESA/TESA/ MESA/TESE + ICSI/IVF kan dermed komme dårlig ut i forhold til tradisjonelle prioriteringskriterier. Disse problemstillingene gjør at denne type 
assistert befruktning av enkelte oppfattes som en negativ rettighet (Elsner 2006), som noe som man har frihet til å bruke, men ikke kan forlange.

\section{Abort, preimplantasjonsdiagnostikk (PGD) og fosterdiagnostikk}

Det kan hevdes at det er motsigende å tilby assistert befruktning for tilstander som kvalifiserer for provosert (sen)abort. Som nevnt medfører de fleste diagnostiserte tilfeller av KS i Danmark provosert abort. Helsevesenet er da med på å frembringe barn med tilstander som det samtidig aksepterer som grunn for provosert abort. To svar gis på denne type seleksjonsrelatert dilemma. Det første er at dette er underlagt foreldrenes selvbestemmelse: Dersom et par ønsker å få et barn med KS, er det deres valg (og deres ansvar), og det samme gjelder dersom de ønsker å avslutte graviditeten (seleksjon fra). Det andre svaret er at man kan bruke PGD for å sikre at barnet ikke får KS (seleksjon til). Det siste svaret forsøker å løse et moralsk dilemma ved hjelp av teknologi, mens det første svaret forsøker å løse en samfunnsmessig og helsepolitisk utfordring (det statsliberale dilemma) på et individualetisk nivå. På den annen side hevdes det at man ikke behøver å gjøre PGD, fordi kromosomavvik hos barn av fedre med KS er sjelden (Ulug 2003), men det øker usikkerheten ved barnets tilstand. Det er fortsatt usikkert om PGD øker risikoen for utviklingsavvik eller sykdom hos det fremtidige barnet, eller om det reduserer muligheten for graviditet. ${ }^{15}$

Det er store variasjoner fra land til land og i hvilke tilstander som helsepersonell hevder kvalifiserer for å avslutte svangerskap (Julian 1989). Samtydig er helsepersonellets kompetanse ved post-diagnostisk veiledning avgjørende for hvor mange som velger å avslutte svangerskapet (Marteau et al. 2002). Fertilitetens kulturelle betydning er viktig for oppfatningen av kromosomavvik ved KS, både i befolkningen og blant profesjonelle (Hashiloni-Dolev 2006). Det er dessuten store variasjoner i hvordan slektninger oppfatter genetisk informasjon, og hvordan de oppfatter syndromer (Whitmarsh 2007). De kan for eksempel definere bort syndromer dersom symptomer ikke forekommer, noe som kan forsterke stigmatiseringsproblemet.

\section{Stigmatisering, seleksjon og mangfold}

Både søkelyset på KS og aspekter som screening for kjønnskromosomaneuploidi kan være stigmatiserende. Klassifiseringen kan være et problem ved at fenotypen domineres av alvorlige tilstander, og det kan føre til at personer med 47,XXY stigmatiseres ved at de vurderes på bakgrunn av de mest alvorlige tilstandene. ${ }^{16}$ 
Stigmatisering kan medføre seleksjon fra (i betydningen negativ eugenikk), og den baserer seg på livskvalitetsvurderinger som virker krenkende på personer med KS. Samlet kan det bidra til og uttrykke en generell negativ oppfatning av denne gruppen (det ekspressivistisk standpunkt, se Solberg 2003a).

En liberal holdning til assistert befruktning for personer med KS kan motvirke en slik tendens. Ved ikke å selektere fra kan man oppfylle formålet i bioteknologiloven om et samfunn med plass til alle. Dette argumentet har vært lite fremme i den internasjonale faglitteraturen om KS, men det er godt kjent fra funksjonshemmedes interesseorganisasjoners standpunkt til assistert befruktning.

\section{Diskusjon: Seleksjon eller ikke?}

Den korte analysen i denne artikkelen viser at seleksjonsproblematikken gjør seg gjeldende i følgende problemstillinger:

1 Seleksjon til av sædceller og egg

2 Infertilitet som biologisk seleksjonsprinsipp (seleksjon $\mathrm{fra}$ )

3 Seleksjon fra som følge av dårligere arvemateriale i befolkningen

4 Seleksjon fra ved abort som følge av KS-diagnose

5 Seleksjon til ved bruk av PGD i kombinasjon med PESA/TESA/ MESA/TESE + ICSI/IVF

6 Ikke seleksjon for å unngå stigmatisering av personer med KS og for ikke å begrense mangfold

For de tre første gjelder seleksjonen egenskaper på et (evolusjons)biologisk nivå. For de to neste gjelder seleksjonen abort og PGD, og ikke problemstillinger knyttet spesifikt til KS. Seleksjonsperspektivet er relevant for den siste problemstillingen.

I tillegg ser vi at en rekke andre moralske problemstillinger gjør seg gjeldende, og disse faller ikke inn under til- og fravalgsproblematikken. Det betyr at seleksjonsperspektivet ikke er dekkende for de moralske utfordringene i det å tilby assistert befruktning til personer med KS. Avhengig av oppfatning vil en også kunne argumentere for at seleksjonsperspektivet ikke er vesentlig for slike vurderinger. Det kan selvsagt skyldes valg av eksempel, det vil si «seleksjonen» av KS som tema: KS kan være sært eller lite representativt for utfordringer med moderne reproduksjonsteknologi. Dessuten kan fremstillingen av aktuelle moralske utfordringer være skjev eller fordomsfull, og drøftingen av seleksjon mangelfull.

Alternativt kan vi bruke KS-eksemplet for å vurdere og videreutvikle seleksjonsmodellen. Én grunn til at modellen er lite anvendelig, er at den 
ikke klargjør relevante skiller. Kun hvis man er mot (eller for) seleksjon som sådan, er den dekkende. Grunnen til det er blant annet at man kan være mot seleksjon fra og for seleksjon til, for eksempel når man mener at man ikke skal tillate abort for visse tilstander, men at man skal fremme (assistert befruktning for) disse tilstandene (som KS). Tilsvarende kan man være for seleksjon fra og mot seleksjon $t i l$, for eksempel ved at man mener at man bør tillate abort for bestemte tilstander, og at man ikke skal tillate assistert befruktning for disse tilstandene.

I tillegg viser KS-eksemplet at vi må være eksplisitte med hensyn til hva seleksjonen gjelder, om den gjelder biologiske forhold (sædcellers viabilitet eller befruktede eggs morfologi), evolusjonsbiologiske forhold (mannlig fertilitet i befolkningen), eksistensielle spørsmål (vil jeg kunne være opphav til et menneske), gruppenivå (personer med KS, selv om KS kan videreføres) eller om den gjelder sosiale egenskaper (språkevne, læringsevne). Seleksjon på ett nivå behøver ikke å bety tilsvarende seleksjon (til/fra) på et annet nivå. Det er selvsagt ikke alltid enkelt å skille disse nivåene fra hverandre. For eksempel henger de genetiske, biologiske, sosiale og kulturelle aspektene ved kjønn sammen, men også her er det mulig og også hensiktsmessig å skille. ${ }^{17}$

Det gjør det vanskelig å skille skarpt mellom seleksjon til og seleksjon fra. Ved KS gjøres en seleksjon til (på gruppenivå) og en seleksjon fra (på cellenivå). Seleksjonen fra på cellenivå er samtidig en seleksjon til. ${ }^{18}$ Det samme gjelder når man gjør en seleksjon fra (eller til) på grunn av gitte egenskaper, men ikke kan unngå andre uønskede egenskaper.

Analysen av utfordringene med KS viser at seleksjonsmodellen også kan utvides til å gjelde helt generelle egenskaper, slik som at det som selekteres til er et (genetisk eget) barn, på samme måte som abort kan oppfattes som en seleksjon fra fordi det som velges bort har egenskapen barn (ved selvbestemt abort). Egenskapene som selekteres, behøver altså ikke å være spesifikke egenskaper, som «alvorlig arvelig sykdom», kjønn, intelligens eller sykdomsdisposisjon.

I tillegg møter vi utfordringer knyttet til hvilke egenskaper som selekteres til eller fra. Selv om det er rimelig bred enighet om at man kan selektere fra i tilfeller der fosteret er «uforenelig med liv» eller har «alvorlig sykdom uten behandlingsmulighet», er det stor uenighet om hva «alvorlig sykdom» og «uten behandlingsmulighet» betyr. Det samme gjelder hva som menes med «(u)ønskede egenskaper». Mens døvhet og kortvoksthet for de fleste mennesker er uønskede egenskaper, er det godt kjent at dette for enkelte (par) er ønskede egenskaper ved et fremtidig barn. Det viser at seleksjonsmodellen må utvides om den skal håndtere relevante praktiske problemstillinger. 


\section{Konklusjon}

Analysen av moralske utfordringer ved bruk av assistert befruktning ved KS viser at den tradisjonelle seleksjonsmodellen med seleksjon til og fra er lite dekkende, og den kan overse viktige problemstillinger. Utfordringene er langt mer komplekse enn hva skillet mellom seleksjon til og seleksjon fra klarer å favne.

Viktige utfordringer er forholdet mellom individuelle valg og følger for samfunnet, samt konsekvenser for en tredjepart (barnet) og populasjonen (fertilitet). Kan det hele og fulle ansvar overføres på de enkelte som får tilbud om assistert befruktning? Har helsevesenet eller profesjonene ikke noe ansvar overhodet når man gjennomfører en behandling med risiko? Hva betyr frihet på ett valgområde (f.eks. fosterdiagnostikk og provosert abort ved KS) for valgfriheten på et annet område (f.eks. assistert befruktning for menn med KS)? Slike spørsmål besvares ikke gjennom å skille mellom seleksjon fra og seleksjon til.

I tillegg kompliserer usikkerhets- og risikovurderinger seleksjonsproblematikken. Dette skyldes blant annet at en tredjeperson er involvert: Hensynet til barnet har vært det viktigste, men ekstra risiko og belastning for kvinnen kan heller ikke ignoreres.

Selv om KS-eksemplet viser seleksjonsmodellens utilstrekkelighet, gir det også stimulus til å revidere og raffinere modellen. Eksemplet viser at det er viktig å definere på hvilket nivå seleksjonen foregår: genetisk, (celle)biologisk, evolusjonsbiologisk, sosialt eller kulturelt. Det understreker at skillet mellom seleksjon til og fra ikke nødvendigvis er den viktigste distinksjonen, og at man kan ha komplekse kombinasjoner av seleksjon til og fra uten at det er inkonsistent. I tillegg til at viktige og relevante problemstillinger er knyttet til hvilke egenskaper som selekteres, og hvordan disse vurderes (som (u)ønsket), kan også helt generelle egenskaper, som barn/ikke barn, være gjenstand for seleksjon.

Det betyr at seleksjonsproblematikken verken er irrelevant eller uviktig dersom den nyanseres og brukes ut over seleksjon til og seleksjon fra. Det kan riktignok redusere dens polemiske kraft, men kanskje øke dens anvendelighet for etikk i praksis.

\section{Noter}

1 I den offentlige debatt brukes ofte betegnelsen «sortering», som i «sorteringssamfunnet». «Sortering» henspeiler på en differensiering, som i prinsippet kan være tilfeldig. Jeg velger i denne sammenhengen heller betegnelsen «seleksjon», fordi det henspeiler på et valg: Man velger noe til eller fra på grunn av spesielle egenskaper.

2 Seleksjonsproblematikken fungerer som en modell for etisk argumentasjon og refleksjon omkring moralske spørsmål innen reproduksjonsteknologi. 
3 Intra-cytoplasmic sperm injection (ICSI) er en metode for assistert befruktning der en sædcelle introduseres i egget på grunn av redusert mannlig fertilitet. Microsurgical epididymal sperm aspiration (MESA) er en metode for uthenting av sædceller fra bitestikler som deretter brukes til ICSI. Percutaneous epididymal sperm aspiration (PESA) er en metode for uthenting av sædceller fra bitestikler. Testicular sperm aspiration (TESA) er en metode for uthenting av spermier (spermatozoa) fra testikler hos menn med azoospermi, ved bruk av en sommerfuglnål. Ved testicular sperm extraction (TESE) hentes spermier ut ved åpen operasjon hos menn med azoospermi. PESA, TESA og TESE brukes i likhet med MESA i forbindelse med ICSI.

4 Preimplantasjonsgenetisk diagnostikk (PGD) er en metode for å undersøke befruktede eggs arveegenskaper før de brukes til assistert befruktning. IVF er forkortelse for in-vitro-fertilisering, tidligere kalt "prøverørsmetoden». PGD kan være aktuelt for å sikre at fosteret ikke er bærer av alvorlig arvelig sykdom uten behandlingsmulighet. Se mer om dette senere.

5 Dersom man i tillegg bruker PGD, er det en seleksjon fra med hensyn til ulike uønskede tilstander.

6 Det gjelder selvsagt bare på et overordnet nivå. For behandling av paret der mannen har KS, må kvinnen gjennomgå IVF selv om hun ikke er infertil.

7 Sæddonasjon gjøres i Norge med identifiserbar donor. Mange infertile menn synes å foretrekke ICSI fremfor sæddonasjon og adopsjon. Dette kan skyldes at alternativene er mindre attraktive, på grunn av ønsker om eller behovet for å føre genene sine videre, ønske om større reproduktiv frihet samt større skille mellom genetisk og sosialt farskap.

8 Grensen for reproduktiv frihet diskuteres ofte i lys av det statsliberale dilemma (Robertson 1994; Nielsen 2005).

9 Dersom kvinnen ikke hormonstimuleres, er behandlingen mindre ressurskrevende, men ikke effektiv. Ved at kvinnen hormonstimuleres, blir behandlingen mer effektiv, men risikoen for komplikasjoner ved fødsel og utviklingsavvik for barn(a) øker på grunn av risiko for flerlinger. Det er også kostnader knyttet til å skaffe og administrere sæddonasjon. Jeg takker anonym fagfellevurderer for denne presiseringen.

10 Nasjonalt kunnskapssenter for helsetjenestens rapport, Mannlig infertilitet: Intracytoplasmatisk spermieinjeksjon (ICSI) med spermier uthentet fra bitestikkel eller testikkel (Rapport 7/2007), viser at kunnskapen om utviklingsavvik for barn unnfanget ved ICSI generelt og ved PESA/TESA/MESA/TESE spesielt, er begrenset. For KS finnes svært lite dokumentert kunnskap.

11 Her kan det bemerkes at paret i de fleste tilfeller er sammen om å få barn, slik at kvinnene ikke nødvendigvis oppfatter det som noen urettmessig belastning, men det kan selvsagt endre seg med endret familieforståelse og familiestrukturer. Dessuten er det uheldig å forutsette at det forholder seg slik.

12 I tillegg til infertilitet kan også andre tilstander, som kan oppfattes som negativt av det fremtidige barnet, overføres, f.eks. cystisk fibrose. Det (gjen)reiser spørsmålet om det finnes grenser for reproduktiv frihet.

13 Det finnes tilfeller der mannen har høyere utdannelse og er svært velfungerende, og der vedkommende ikke kjente KS-diagnosen før det ble gjort utredning for infertilitet.

14 Oversettelsen er gjort av Sosial- og helsedirektoratet og Bioteknologinemnda. Se Bioteknologinemnda (2006).

15 PGD er fortsatt kontroversielt for mange, mens andre vil hevde at man ikke bør gjøre PESA/TESA/MESA/TESE + ICSI/IVF med mindre man også gjør PGD. Alternativet vil i mange tilfeller være fosterdiagnostikk og senabort. Argumentet kan da være at 
når selvbestemmelsen står så sterkt innen reproduksjon (fosterdiagnostikk og abort), er det urimelig at den begrenses for PGD (Solberg 2005).

16 Det kan argumenteres for screening for å oppnå tidlig tilpassing, f.eks. i språkopplæring, men slik opplæring kan selvsagt gjøres uavhengig av karyotyping. Likevel kan man tenke seg at man kan oppnå bedre fertilitetsbehandling ved tidlig diagnose. Dessuten anbefales testosteronterapi av fagmiljøene uten at det foreligger gode studier for effekten av dette (Bojesen 2007).

17 Tilsvarende kan det være viktig å skille mellom hvilke enheter som selekteres; a) om det er mennesker (hvem som skal få reprodusere seg), b) om det er fostre som skal bæres frem, c) om det er befruktede egg som skal implanteres, eller d) om det er ubefruktede kjønnsceller. Felles for alle er utfordringen ved å predikere det resulterende barnets egenskaper.

18 Tilsvarende er det ved kjønnsseleksjon, fordi å selektere fra en egenskap i praksis betyr å selektere til en annen egenskap.

\section{Litteratur}

Abolghasemi, H., Amid, A., Zeinali, S., Radfar, M. H., Eshghi, P., Rahiminejad, M. S., Ehsani, M. A., Najmabadi, H., Akbari, M. T., Afrasiabi, A., Akhavan-Niaki, H. \& Hoorfar, H. (2007) Thalassemia in Iran: Epidemiology, prevention, and management. J Pediatr Hematol Oncol, 29 (4), s. 233-238.

Aftenposten.no (2007) Sorteringssamfunn? Debattforum. Lastet ned 6. mars 2008 fra http://debatt.aftenposten.no/item.php?GroupID=10\&ThreadID=182 487

Bioteknologinemnda (2004) Et barn i ditt bilde - etiske dilemmaer ved livets begynnelse. Oslo: Bioteknologinemnda.

Bioteknologinemnda (2006a) Innspill til revisjon av bioteknologiloven preimplantasjonsdiagnostikk. Brev til Helse- og omsorgsdepartementet, 14. mars 2006.

Bioteknologinemnda (2006b) Vedrørende rundskriv for vurdering av par ved assistert befruktning. Brev til Helse- og omsorgsdepartementet, 17. november 2006. Lastet ned 6. mars 2008 fra http://www.bion.no/uttalelser/2006_17_11_ rundskriv_for_vurdering_av_par_ved_assistert_befruktning.pdf

Bioteknologinemnda (2007) Assistert befruktning til par der mannen har Klinefelters syndrom. Brev til Sosial- og helsedirektoratet, 11. september 2007.

Bojesen, A., Juul, S. \& Gravholt, C. H. (2003) Prenatal and postnatal prevalence of Klinefelter syndrome: A national registry study. J Clin Endocrinol Metab, 88, s. 622-626.

Bojesen, A. \& Gravholt, C. H. (2007) Klinefelter syndrome in clinical practice. Nat Clin Pract Urol, 4 (4), s. 192-204.

Bozkurt, G. (2007) Results from the North Cyprus thalassemia prevention program. Hemoglobin, 31 (2), s. 257-264.

Den norske legeforenings råd for legeetikk (2007) Behandling med assistert befruktning av pasienter med Klinefelter syndrom. Brev til Sosial- og helsedirektoratet, 4. september 2007.

Denschlag, D., Tempfer, C., Kunze, M., Wolff, G. \& Keck, C. (2004) Assisted reproductive techniques in patients with Klinefelter syndrome: A critical review. Fertil Steril, 82, s. 775-779. 
Elsner, D. (2006) Just another reproductive technology? The ethics of human reproductive cloning as an experimental medical procedure. J Med Ethics, 32 (10), s. 596-600.

Harris, J. (2004) On cloning. London: Routledge.

Harris, J. \& Holm, S. (1998) The future of human reproduction: Ethics, choice, and regulation. Oxford: Clarendon Press.

Hashiloni-Dolev, Y. (2006) Genetic counseling for sex chromosome anomalies (SCAs) in Israel and Germany: Assessing medical risks according to the importance of fertility in two cultures. Med Anthropol Q., 20 (4), s. 469-486.

Human Fertilisation and Embryology Authority (HFEA) (2005) Tomorrow's children. London: HFEA. Lastet ned 6. mars 2008 fra http://www.britishfertilitysociety.org.uk/practicepolicy/documents/05_04_Tomorrow's_Children.pdf

Hviid Nielsen, T. (2005) Det statsliberale dilemma. Nytt Norsk Tidsskrift, 2, s. 198211.

Jørgensen, N., Asklund, C., Carlsen, E. \& Skakkebæk, N. E. (2006) Coordinated European investigations of semen quality: Results from studies of Scandinavian young men is a matter of concern. International Journal of Andrology, 29 (1), s. $54-61$.

Julian, C., Huard, P., Gouvernet, J., Mattei, J. F \& Ayme, S. (1989) Physicians' acceptability of termination of pregnancy after prenatal diagnosis in southern France. Prenat Diagn, 9 (2), s. 77-89.

Klinefelter, H., Reifenstein, E. C. \& Albright, F. (1942) Syndrome characterized by gynecomastia, aspermatogenesis without a-Leydigism and increased secretion of follicle-stimulating hormone. J Clin Endocrinol Metab, 2, s. 615-622.

Marteau, T. M., Nippert, I., Hall, S., Limbert, C., Reid, M., Bobrow, M., Cameron, A., Cornel, M., van Diem, M., Eiben, B., Garcia-Minaur, S., Goujard, J., Kirwan, D., McIntosh, K., Soothill, P., Verschuuren-Bemelmans, C., de Vigan, C., Walkinshaw, S., Abramsky, L., Louwen, F., Miny, P. \& Horst, J. (2002) DADA Study Group. Decision-making after diagnosis of fetal abnormality. Outcomes of pregnancies diagnosed with Klinefelter syndrome: The possible influence of health professionals. Prenat Diagn, 22 (7), s. 562-566.

Robertson, J. A. (1994) Children of choice. Freedom and the new reproductive technologies. Princeton: Princeton University Press.

Saugstad, O. D. (2007) Når grenser flyttes. Om ufødt liv, helse og forskning. Oslo: Avenir Forlag.

Schiff, J. D., Palermo, G. D., Veeck, L. L., Goldstein, M., Rosenwaks, Z. \& Schlegel, P. N. (2005) Success of testicular sperm extraction [corrected] and intracytoplasmic sperm injection in men with Klinefelter syndrome. J Clin Endocrinol Metab, 90, s. 6263-6267.

Solberg, B. (2003a) Etikken i å si nei til sorteringssamfunnet. Genialt, 3, s. 20-23.

Solberg, B. (2003b) Sortering av liv? Etiske hensyn ved å lage barn med og uten genetisk risikoinformasjon. Trondheim: Filosofisk institutts publiseringsserie, NTNU.

Solberg, B. (2005) The concept of selection: When are you selecting? Is it discriminatory? I PGD and embryo selection. Report from an international conference on preimplantation genetic diagnosis and embryo selection, red. Nordic Comittee on Bioethics, s. 93-96. København: TemaNord.

Tännsjö, T. (2008) Procreative liberty or collective responsibility. XVIII Nordic IVF Meeting, Oslo, Proceedings, 18, s. 17-18. 
Ulug, U., Bener, F., Akman, M. A. \& Bahceci, M. (2003) Partners of men with Klinefelter syndrome can benefit from assisted reproductive technologies. Fertil Steril, 80 (4), s. 903-906.

Von Düring, V. (2007) Personlig meddelelse.

Whitmarsh, I., Davis, A. M., Skinner, D. \& Bailey, D. B. Jr. (2007) A place for genetic uncertainty: Parents valuing an unknown in the meaning of disease. Soc Sci Med, 65 (6), s. 1082-1093.

Zhu, J. L., Bas, O., Obel, C., Bille, C. \& Olsen, J. (2006) Infertility, infertility treatment, and congenital malformations: Danish national birth cohort. BMJ, 333 (7570), s. 665-666. 